\title{
フラックス法によるチタン酸カリウム繊維の合成
}

\author{
藤 木良規・泉富士夫 \\ (科学技尃序 無機材質研究所)
}

\begin{abstract}
チタン酸カリウム繊維が $\mathrm{K}_{2} \mathrm{MoO}_{4}$ 及び $\mathrm{K}_{2} \mathrm{WO}_{4}$ フラックスを用いて効果的に育成できた。熔融 塩の塩基性度は $\mathrm{K}_{2} \mathrm{O}$ 成分と $\mathrm{MoO}_{3}$ または $\mathrm{WO}_{3}$ 成分の配合比により制御され，之れにより合成 相を制御することができる. 出発瀻維組成を $\left(\mathrm{K}_{2} \mathrm{O}\right)_{x} \cdot \mathrm{TiO}_{2}$ 式で表示すると, $\mathrm{K}_{2} \mathrm{MoO}_{4}$ フラックス の場合 $\mathrm{K}_{2} \mathrm{Ti}_{6} \mathrm{O}_{13}$ 単独相は $x \leq 1 / 6$ で, $\mathrm{K}_{2} \mathrm{WO}_{4}$ フラックスの場合は $x \leq 177$ で台成できる. 両 フラックスともこの $x$ 值より大きい場合は $\mathrm{K}_{2} \mathrm{Ti}_{6} \mathrm{O}_{13}$ 上 $\mathrm{K}_{2} \mathrm{Ti}_{4} \mathrm{O}_{9}$ の混合相繊維杂生成し， $x$ 值の 大きい程後者の量が多くなる.

反応初期は $\mathrm{TiO}_{2}$ 粒子が溶解することなく液相中の $\mathrm{K}_{2} \mathrm{O}$ 成分上反応する固-液界面反応が優勢 であるが，漸次，サイズ效果により溶解-析出反応に移行方る．短繊維（<1 mm）の合成注前者の 反応が重要で, 比表面積の大きい $\mathrm{TiO}_{2}$ 粒子ほど反応活性であるが, 長繊維の合成に法徭者の反忘 が重要で, 高い過飽和度が維持できる徐泠法が最適であった， その結果，平均 $5 \mathrm{~mm}$, 最大 $10 \mathrm{~mm}$ 程度の繊維が成長した。

(5/27/1976 受付)
\end{abstract}

\section{Flux Growth of Potassium Titanate Fibers}

\author{
Yoshinori FUJIKI and Fujio IZUMI \\ National Institute for Researches in Inorganic Materials,
Niihari-gun, Ibaraki, 300-31
}

Potassium titanate fibers were grown from the $\mathrm{K}_{2} \mathrm{O}-\mathrm{TiO}_{2}$ system in fluxes of $\mathrm{K}_{2} \mathrm{MoO}_{4}$ and $\mathrm{K}_{2} \mathrm{WO}_{4}$. The basicities of flux melts were controlled by adding $\mathrm{K}_{2} \mathrm{O}$ as a basic component, and $\mathrm{MoO}_{3}$ or $\mathrm{WO}_{3}$ as an acid one.

When starting compositions are represented by the formula $\left(\mathrm{K}_{2} \mathrm{O}\right)_{x} \cdot \mathrm{TiO}_{2}$, potassium hexatitanate $\left(\mathrm{K}_{2} \mathrm{Ti}_{6} \mathrm{O}_{13}\right)$ in the form of colorless acicular crystals were usually synthesized with less than $x=1 / 6$ in the $\mathrm{K}_{2} \mathrm{MoO}_{4}$ flux melt, and with less than $x=1 / 7$ in the $\mathrm{K}_{2} \mathrm{WO}_{4}$ flux melt. Mixtures of potassium hexatitanate and tetratitanate $\left(\mathrm{K}_{2} \mathrm{Ti}_{4} \mathrm{O}_{9}\right)$ in the form of colorless bundle fibers were always obtained with more than these $x$ values.

The solid-liquid interface reaction is predominant at the earlier stage of the flux reaction, followed by the recrystallization reaction at the later stage. Consequently, the growth rate and shape of short fibers at the earlier stage were markedly affected by the size of $\mathrm{TiO}_{2}$ particles, and a supersaturation needs to be controlled to grow long fibers. Fibers of the mixed phase of $\mathrm{K}_{2} \mathrm{Ti}_{6} \mathrm{O}_{13}$ and $\mathrm{K}_{2} \mathrm{Ti}_{4} \mathrm{O}_{9}$ obtained by the slow-cooling method reached up to $5 \mathrm{~mm}$ in average length (maximum $10 \mathrm{~mm}$ ).

[Received May 27,1976]

\section{1. 緒言}

チタン酸カリウム繊維は断熱性，耐化学性に優れ，さ らに充塤剤や分散剤を用いなくても成形や分散し舄いた めに, 断熱・耐火材, 顔料, 沪過材, 触媒の担体, プラ スチック補強材，七メントの複合材など非常に広い用途 が期待されるので注目されている人工鉣物繊維である.
本物質は一般式 $\mathrm{K}_{2} \mathrm{O} \cdot n \mathrm{TiO}_{2}$ だ示され， $n$ は 1 6 寺 で知られており，n=6のものが最も高融点 ${ }^{1)}\left(1370^{\circ} \mathrm{C}\right.$ 士 $15^{\circ} \mathrm{C}$ ) で優れた特性を示している.

合成には焼成法(1) 3), 熔融法(5), フララックス法3) 9), 水熱法4),10) 14)があるが，纎維状さするにはフラックス 法か水熱法が適している. フラックス法では $\mathrm{KCl}$ 単独 
および $\mathrm{KCl}-\mathrm{KF}$ 系フラックス ${ }^{3), 6)}$ が工業的に, $\mathrm{K}_{2} \mathrm{O}-\mathrm{B}_{2} \mathrm{O}_{3}$ 系および $\mathrm{K}_{2} \mathrm{O}-\mathrm{Na}_{2} \mathrm{O}-\mathrm{B}_{2} \mathrm{O}_{3}$ 系フラックス ${ }^{7,9)}$ が研究的に 使用されている.

本報では従来のフラックス合成法を検討し，八ロゲン 化物類より高溶媒能で低蒸気圧，硼酸塩類よりも低粘性 で化学的易溶性があり, かつ高収率，大型繊維化の可能 性をもつフラックスを探索した結果，タングステン酸塩 類，モリブデン酸塩類がこの目的に非常に有効であるこ とを見出したのでその合成条件について述べると共に反 応機構についても考察定加えた。

\section{2. 実験}

\section{1 出発原料之実験方法}

実験に用いた試薬は市販特級の結晶質二酸化チタン (ルチル上アナターゼ), 炭酸カリウム, 無水モリブデン 酸カリウム，無水タングステン酸カリウムである.なお 用いたアナターゼには二種あり，一種は高結晶性試薬 （以下アナターゼ(I )) であり，他はチタン(IV) イソ プロポキシドを加水分解して生成した非晶質二酸化チタ ン水和物 $\left(\mathrm{TiO}_{2} \cdot n \mathrm{H}_{2} \mathrm{O}\right)$ æ $100^{\circ} \mathrm{C}, 15$ 時間で脱水して 得た微粒子低結晶性アナターゼ（以下アナターゼ(II)) である。

出発原料の繊維組成を表示するのに $1 \mathrm{~mol} の \mathrm{TiO}_{2} に$ 対して加えた $\mathrm{K}_{2} \mathrm{O}$ (実際には $\mathrm{K}_{2} \mathrm{CO}_{3}$ ) の mol 数を $x$ として便宜的に $\left(\mathrm{K}_{2} \mathrm{O}\right)_{x} \cdot \mathrm{TiO}_{2}$ 式を用いることにする.

合成方法は出発繊維組成上して $x$ を，1/6，1/5，1/4.

1/3 までを調合し，これらの調合物とフラックスとを種 々モル百分率で混合し， $100 \mathrm{~m} l$ 白金坩堝を用いてシリ コニット電気炉で合成した. 繊維状結晶の育成には一定 温度保持法と徐泠法で検討し, 徐冷速度は $4^{\circ} \mathrm{C} / \mathrm{h}$ であっ た. 反応はいずれも静置状態で行い擋拌しなかった．所 定温度で所定時間反応後坩堝を取り出し大気中で放冷し た．得られた䋊維㳂冰または温水でフラックスを溶解
除去し，水洗後 $120^{\circ} \mathrm{C}$ で 10 時間以上乾燥させた。

\section{2 繊維の同定, 測定および観察}

合成反応の前後で坩堝ごと秤量し，フラックスの蒸発 量を求めた. 合成繊維の収率は乾燥後の繊維を秤量し出 発原料に対する重量割合から求めた. 繊維の同定は粉末 X 線回折により行い, ASTM カード值 ${ }^{4)}{ }^{15}$ と比較した。 繊維の観察は主に偏光顕微鏡と走査型電子顕微鏡で行 い，繊維長の測定は偏光顕微鏡でマイクロメーターを用 いて測定した。ただし，大形繊維については実体顕微鏡 下で測定した。この測定には代表值の選択に問題がある が，ここでは一視野の中で認められる平均的な繊維と最 大のものについて測定し, これを数視野について行いそ の平均值で表示した.

\section{3. 結果及び考察}

\section{$3.1 \mathrm{~K}_{2} \mathrm{MoO}_{4}$ フラックス}

$\mathrm{K}_{2} \mathrm{MoO}_{4}$ フラックスを用いた一定温度下の合成で種々 出発繊維組成に対する反応条件, 反応相, 平均繊維長の 関係を表 1 に示す.この表の示す重要なことは反応相が 出発組成の $\mathrm{K}_{2} \mathrm{O}, \mathrm{MoO}_{3}, \mathrm{TiO}_{2}$ 成分の混合比により制御 できることで，換言すれば熔融液の塩基性条件がこれら の成分の配合比により敏感に影響を受けて反応相を決定 していることである.便宜的に出発綫維組成式 $\left\{\left(\mathrm{K}_{2} \mathrm{O}\right)_{x}\right.$ ・ $\left.\mathrm{TiO}_{2}\right\}$ を用いれば， $x$ が $0 \sim 1 / 6$ の範园内に調合する と六チタン酸カリウム $\left(\mathrm{K}_{2} \mathrm{Ti}_{6} \mathrm{O}_{13}\right)$ の単独相が生成す る. ただし， $x=0$ の場合にはフラックスに対して $\mathrm{TiO}_{2}$ が $35 \mathrm{~mol} \%$ までで, $40 \mathrm{~mol} \%$ 以上ではルチル相と共存 する。

次に出発組成の $x$ を $1 / 5$ 以上にして漸次 $\mathrm{K}_{2} \mathrm{O}$ 成分を 多く含むものに調合すれば, 六チタン酸カリウムと一緒 に四チタン酸カリウム $\left(\mathrm{K}_{2} \mathrm{Ti}_{4} \mathrm{O}_{9}\right)$ 相が生成してくる. すなわち $\mathrm{TiO}_{2}$ に対して $\mathrm{K}_{2} \mathrm{O}$ 成分が多くなるほど，換 言すれば熔融液の塩基性度が高くなるほど四チタン酸力

Table 1. Growth conditions and results by the isothermal method using $\mathrm{K}_{2} \mathrm{MoO}_{4}$ flux.

\begin{tabular}{|c|c|c|c|c|c|c|}
\hline No. & $\underset{(\mathrm{mol} \%)}{\text { Starting composition }}$ & $\underset{(\operatorname{mol} \%)}{\text { Flux }}$ & $\begin{array}{l}\text { Temperature } \\
\left({ }^{\circ} \mathrm{C}\right)\end{array}$ & $\begin{array}{l}\text { Duration } \\
\text { (h) }\end{array}$ & Products* & $\begin{array}{l}\text { Average size }{ }^{* *} \\
(\mathrm{~mm})\end{array}$ \\
\hline 1 & $\mathrm{TiO}_{2} 30$ & $\mathrm{~K}_{2} \mathrm{O} \cdot \mathrm{MoO}_{3} 70$ & 1180 & 28 & $\mathrm{H}$ & $\begin{array}{l}0.002 \times 0.15 \\
(0.01 \times 0.25)\end{array}$ \\
\hline 2 & $\left(\mathrm{~K}_{2} \mathrm{O}\right)_{1 ;} \cdot \mathrm{TiO}_{22} 30$ & $\mathrm{~K}_{2} \mathrm{O} \cdot \mathrm{MoO}_{3} 70$ & 1180 & 40 & $\mathrm{H}$ & $\begin{array}{l}0.003 \times 0.35 \\
(0.02 \times 1.0)\end{array}$ \\
\hline 3 & $\left(\mathrm{~K}_{2} \mathrm{O}_{1,6} \cdot \mathrm{TiO}_{2} 30\right.$ & $\mathrm{K}_{2} \mathrm{O} \cdot \mathrm{MoO}_{3} 70$ & 1180 & 56 & $\mathrm{H}$ & $\begin{array}{c}0.01 \times 0.5 \\
(0.02 \times 1.0)\end{array}$ \\
\hline 4 & $\left(\mathrm{~K}_{2} \mathrm{O}\right)_{1 / 6} \cdot \mathrm{TiO}_{2} 40$ & $\mathrm{~K}_{2} \mathrm{O} \cdot \mathrm{MoO}_{3} 60$ & 1220 & 45 & $\mathrm{H}$ & $\begin{array}{l}0.0250 \times .6 \\
(0.14 \times .0)\end{array}$ \\
\hline 5 & $\left(\mathrm{~K}_{2} \mathrm{O}\right)_{1: 6} \cdot \mathrm{TiO}_{2} 30$ & $\mathrm{~K}_{2} \mathrm{O} \cdot 1.1 \mathrm{MoO}_{3} 70$ & 1180 & 41 & $\mathrm{H}+\mathrm{R}$ & $\begin{array}{c}0.02 \times 0.35 \\
(0.02 \times 1.0)\end{array}$ \\
\hline 6 & $\left(\mathrm{~K}_{2} \mathrm{O}\right)_{1 ; 5} \cdot \mathrm{TiO}_{2} 30$ & $\mathrm{~K}_{2} \mathrm{O} \cdot \mathrm{MoO}_{3} 70$ & 1180 & 50 & $\mathrm{H}+\mathrm{T}$ & $\begin{array}{l}0.003 \times 0.2 \\
(0.02 \times 1.0)\end{array}$ \\
\hline 7 & $\left(\mathrm{~K}_{2} \mathrm{O}\right)_{1: 4} \cdot \mathrm{TiO}_{2} 30$ & $\mathrm{~K}_{2} \mathrm{O} \cdot \mathrm{MoO}_{3} 70$ & 1180 & 46 & $\mathrm{H}+\mathrm{T}$ & $\begin{array}{c}0.02 \times 0.35 \\
(0.05 \times 1.0)\end{array}$ \\
\hline 8 & $\left(\mathrm{~K}_{2} \mathrm{O}\right)_{1 / 3} \cdot \mathrm{TiO}_{2} 30$ & $\mathrm{~K}_{2} \mathrm{O} \cdot \mathrm{MoO}_{3} 70$ & 1180 & 65 & $\mathrm{H}+\mathrm{T}$ & $\begin{array}{c}0.2 \times 5.0 \\
(0.3 \times 10.0)\end{array}$ \\
\hline
\end{tabular}

* $\mathrm{H}$ : potassium hexatitanate, $\mathrm{T}$ : potassium tetratitanate, $\mathrm{R}:$ rutile

** It is shown as diameter $\times$ length; average diameter of bunchy fibers is shown for the mixed phase of $H$ and $\mathrm{T}$. Values in parentheses represent maximum size. 
Table 2. Growth conditions and results by the isothermal method using $\mathrm{K}_{2} \mathrm{WO}_{4}$ flux.

\begin{tabular}{|c|c|c|c|c|c|c|}
\hline No. & $\begin{array}{l}\text { Starting composition } \\
(\mathrm{mol} \%)\end{array}$ & $\underset{(\mathrm{mol} \%)}{\text { Flux }}$ & $\begin{array}{l}\text { Temperature } \\
\text { ('C) }\end{array}$ & $\begin{array}{l}\text { Duration } \\
\text { (h) }\end{array}$ & Products* & $\begin{array}{l}\text { Average size** } \\
(\mathrm{mm})\end{array}$ \\
\hline 1 & $\mathrm{TiO}_{2} 20$ & $\mathrm{~K}_{2} \mathrm{O} \cdot \mathrm{WO}_{3} 80$ & 1180 & 65 & $\mathrm{H}$ & $\begin{array}{l}0.02 \times 0.5 \\
(0.02 \times 1.0)\end{array}$ \\
\hline 2 & $\mathrm{TiO}_{2} 30$ & $\mathrm{~K}_{2} \mathrm{O} \cdot \mathrm{WO}_{3} 70$ & 1180 & 47 & $\mathrm{H}+\mathrm{R}$ & $\begin{array}{c}0.01 \times 0.25 \\
(0.02 \times 0.5)\end{array}$ \\
\hline 3 & $\left(\mathrm{~K}_{2} \mathrm{O}\right)_{1,7} \cdot \mathrm{TiO}_{2} 30$ & $\mathrm{~K}_{2} \mathrm{O} \cdot \mathrm{WO}_{3} 70$ & 1180 & 40 & $\mathrm{H}$ & $\begin{array}{l}0.005 \times 0.35 \\
(0.01 \times 0.6)\end{array}$ \\
\hline 4 & $\left(\mathrm{~K}_{2} \mathrm{O}\right)_{1 / 6} \cdot \mathrm{TiO}_{2} 20$ & $\mathrm{~K}_{2} \mathrm{O} \cdot \mathrm{WO}_{3} 80$ & 1180 & 48 & $\mathrm{H}+\mathrm{T}$ & $\begin{array}{l}0.01 \times 0.35 \\
(0.1 \times 10.0)\end{array}$ \\
\hline 5 & $\left(\mathrm{~K}_{2} \mathrm{O}\right)_{1 / 6} \cdot \mathrm{TiO}_{2} 30$ & $\mathrm{~K}_{2} \mathrm{O} \cdot \mathrm{WO}_{3} 70$ & 1180 & 47 & $\mathrm{H}+\mathrm{T}$ & $\begin{array}{c}0.01 \times 0.35 \\
(0.02 \times 0.5)\end{array}$ \\
\hline 6 & $\left(\mathrm{~K}_{2} \mathrm{O}\right)_{1 / 6} \cdot \mathrm{TiO}_{2} 30$ & $\mathrm{~K}_{2} \mathrm{O} \cdot 1.05 \mathrm{WO}_{3} 70$ & 1180 & 46 & $\mathrm{H}+\mathrm{T}$ & $\begin{array}{l}0.01 \times 0.35 \\
(0.02 \times 0.5)\end{array}$ \\
\hline 7 & $\left(\mathrm{~K}_{2} \mathrm{O}\right)_{1,6} \cdot \mathrm{TiO}_{2} 30$ & $\mathrm{~K}_{2} \mathrm{O} \cdot 1.1 \mathrm{WO}_{3} 70$ & 1180 & 49 & $\mathrm{H}+\mathrm{R}$ & $\begin{array}{c}0.01 \times 0.35 \\
(0.02 \times 1.5)\end{array}$ \\
\hline 8 & $\left(\mathrm{~K}_{2} \mathrm{O}\right)_{1 / 5} \cdot \mathrm{TiO}_{2} 30$ & $\mathrm{~K}_{2} \mathrm{O} \cdot \mathrm{WO}_{3} 70$ & 1180 & 65 & $\mathrm{H}+\mathrm{T}$ & $\begin{array}{l}0.02 \times 0.35 \\
(0.02 \times 0.5)\end{array}$ \\
\hline 9 & $\left(\mathrm{~K}_{2} \mathrm{O}\right)_{1 / 4} \cdot \mathrm{TiO}_{2} 30$ & $\mathrm{~K}_{2} \mathrm{O} \cdot \mathrm{WO}_{3} 70$ & 1180 & 58 & $\mathrm{H}+\mathrm{T}$ & $\begin{array}{l}0.2 \times 5.0 \\
(0.3 \times 10.0)\end{array}$ \\
\hline
\end{tabular}

* $\mathrm{H}$ : potassium hexatitanate, $\mathrm{T}:$ potassium tetratitanate, $\mathrm{R}:$ rutile

** It is shown as diameter $\times$ length; average diameter of bunchy fibers is shown for the mixed phase of $H$ and $T$. Values in parentheses represent maximum size.

リウム相の量が増大する傾向を示した. 一方, 出発繊維 組成を $x=1 / 6$ に調合しても酸性成分よして $\mathrm{MoO}_{3}$ を $\mathrm{K}_{2} \mathrm{MoO}_{4}$ に $0.1 \mathrm{~mol}$ 数添加した熔融液中では六チタン 酸カリウム相の他に $\mathrm{TiO}_{2}$ (ルチル) 相が微量生成し, $\mathrm{MoO}_{3}$ 成分の添加量の増加と共に熔融液の塩基性度が低 下するので，これに伴って $\mathrm{TiO}_{2}$ 相が増大する傾向を示 した.

フラックスの蒸発量は一般に温度, 反応時間, 組成, 坩堝の蓋の状態などにより影響される. 表 1 の全ての実 験では蓋をしないで行った結果，普通 $1 \mathrm{wt} \%$ 前後で， 最大でも $5 \mathrm{wt} \%$ 程度の非常に低い蒸発舅を示した.こ れはフラックスの蒸気圧が低いのみならず，生成した繊 維が比重差により熔融液の表面近くで成長し, 蒸発防止 の作用をしているためである。

繊維の生成状態は一般に六チタン酸カリウム単独相の 場合は集合しないか，集合しても非常に粗密な毛せん状 を示し, 特に $x$ が $1 / 6 \sim 1 / 7$ 付近ではそうであるが, $x=0$ だは比較的稠密な毛せん状集合体を示す量が多くなる。

一方, 六チタン酸カリウムと四チタン酸カリウムの混 合相の場合は $x$ が $1 / 5$ から大きくなるほど稠密な集合状 態を示す. こ机は $\mathrm{TiO}_{2}$ 成分に詨して $\mathrm{K}_{2} \mathrm{O}$ 成分が増大 するほど, 四チタン酸カリウム相の量が増大するが，こ の順序に従って繊維長がより長く, より細くなる.つま り繊維性がよくなるので集合体の稠密度が増大するもの と考えられる.なお， $x=1 / 3$ では繊維の稠密集合体中 に六チタン酸カリウムの柱状結晶（最大 $1 \times 20 \mathrm{~mm}$ ) が 数\%生成し， $x=1 / 2$ では繊維性が著しく低下した.こ の $x=1 / 2$ の組成では明瞭ではないがさらに別相が生成 したためと思われる。

また, $\mathrm{K}_{2} \mathrm{MoO}_{4}$ フラックスの代りに $\mathrm{K}_{2} \mathrm{CO}_{3}$ と $\mathrm{MoO}_{3}$ の等モル比混合物を用いても繊維合成のすべての結果は 同じであった.

\section{$3.2 \quad \mathrm{~K}_{2} \mathrm{WO}_{4}$ フラックス}

$\mathrm{K}_{2} \mathrm{WO}_{4}$ フラックスを用いた一定温度下の合成で, 種 々出発䋊維組成に対する反応条件, 反応相, 平均繊維長の 関係を表 2 に示す．この表の示す重要なことは $\mathrm{K}_{2} \mathrm{MoO}_{4}$ と同様に反応相が出発組成の $\mathrm{K}_{2} \mathrm{O}, \mathrm{WO}_{3}, \mathrm{TiO}_{2}$ 成分の 配合比の影響を敏感に受け，換言すれば熔融液の塩基性 条件が反応相を決定していることである.しかし，出発 組成と反応相の相関性は $\mathrm{K}_{2} \mathrm{MoO}_{4}$ の場合と異なるので 注意を要する. 出発繊維組成を $x=1 / 6$ の化学量論比に 調合すれば $\mathrm{K}_{2} \mathrm{MoO}_{4}$ 熔融液中では六チタン酸カリウム 単独相だけが生成したが，本熔融液中では六チタン酸力 リウムと四チタン酸カリウムが必ず共存する。これは生 成相の量的割合から $\mathrm{K}_{2} \mathrm{MoO}_{4}$ の場合の $x=1 / 5$ にほぼ 相当する. 六チタン酸カリウム単独相を合成するために は出発組成の $\mathrm{K}_{2} \mathrm{O}$ 成分を更に少なくし， $x=1 / 7$ 以下に する必要がある. また, 出発繊維組成として $\mathrm{TiO}_{2}$ だけ を用いても六チタン酸カリウムの単独相を合成すること ができる.この場合フラックスに対して $\mathrm{TiO}_{2}$ 成分が 30 $\mathrm{mol} \%$ 以上になるとルチル相が共存する. これは $\mathrm{TiO}_{2}$ 成分の増加による塩基性度の低下に起因するためと思わ れる。

一方, 出発繊維組成を $x=1 / 6$ に調合しても酸性成分 として $\mathrm{WO}_{3}$ を余分に $0.1 \mathrm{~mol}$ 数以上添加した熔融液 中では六チタン酸カリウム相の他にルチル相が生成し, $\mathrm{WO}_{3}$ の添加量に比例して増大すること, また， $x=1 / 6$ のモル比よりも多くの $\mathrm{K}_{2} \mathrm{O}$ 成分を添加するほど四チタ ン酸カリウム相が増大する傾向は $\mathrm{K}_{2} \mathrm{MoO}_{4}$ の場合と同 様である.な拉, フラックスの蒸発量, 合成繊維の集合 状態なども $\mathrm{K}_{2} \mathrm{MoO}_{4}$ の場合と同様な結果を示した.

以上の $\mathrm{K}_{2} \mathrm{MoO}_{4}$ と $\mathrm{K}_{2} \mathrm{WO}_{4}$ フラックスの比較から次 のような興味あることがわかる. 六チタン酸カリウム単 独相は熔融液の適当な塩基性条件でのみ生成するという 
事実加らみると，上述の反応系の検討加ら $\mathrm{K}_{2} \mathrm{WO}_{4}$ フラ ックスの方が $\mathrm{K}_{2} \mathrm{MoO}_{4}$ よりも定性的に高い塩基性度を示 すことになる．これは酸化物として本質的に $\mathrm{MoO}_{3}$ より も $\mathrm{WO}_{3}$ の方が塩基性度が高いことでよく説明できる ${ }^{16)}$. しかし，上述の $\mathrm{TiO}_{2}$ だけを用いた場合のルチル相の出 現について両フラックスを比較すると， $\mathrm{TiO}_{2}$ の $\mathrm{mol}$ 配 合比が $\mathrm{K}_{2} \mathrm{WO}_{4}$ の方が低、にも拘わらずルチル相が出現 しており，この点からみれば $\mathrm{K}_{2} \mathrm{WO}_{4}$ の方が低塩基性に なるが，その詳細は現在不明である。

なお，両フラックスを用いて $\mathrm{K}_{2} \mathrm{Ti}_{4} \mathrm{O}_{9}$ 単独相の合成を 試みたが，いっも $\mathrm{K}_{2} \mathrm{Ti}_{6} \mathrm{O}_{13}$ 相と共存し成功しなかった。

\section{3 織維合成の反応機構とその成長速度}

前述のように $\mathrm{K}_{2} \mathrm{MoO}_{4}$ フラックス定用いて出発繊維 組成を $x=1 / 6$, つまり $\left(\mathrm{K}_{2} \mathrm{O}\right)_{1 / 6} \cdot \mathrm{TiO}_{2}$ に調合すれば合成 相は六チタン酸カリウム単独相である。表1.中の No. 3 がこれに相当し，この合成条件下で繊維長の反応時閒依 存性を調べた結果が図 1 中の A, B 曲線である。これらの 曲線の示す重要なことは, 約 25 時閒迄の短時閒内の成長 率とそれよりる長時間での成長率に差を生じていること である。この理由法反応機構の相違によるものである.

短時間内で合成した繊維は大部分の緎維長が揃ってい るのが特長である。そして，収率は反応時間 5 時間でも 95\% 以上であること,また後で詳述するように繊維の 直径が原料二酸化チタンの粒径と明膫な比例関倸をもつ こと,その上に種子効果がないことなどから,繊維合成の 初期段階での主要な反応機構は固-液界面反応であるう。 一般にフラックス法の結晶成長は溶解一析出反応である が，本実験の初期段階では少なくとも固体の $\mathrm{TiO}_{2}$ 粉末 の大部分溶解することなく熔融液中の $\mathrm{K}_{2} \mathrm{O}$ 成分と反 応し, 六チタン酸カリウムを生成するものと推定され る. 勿論, 一部には僅かであるが溶解一析出反応も起こ っているのであるう，反応時閒が 20 時間以上になると， 初生的に生成した六チタン酸カリウムの一部はフラック ス中に溶解し析出して再結晶化する反応が優勢となり, この割合が反応時間に比例して多くなる. その結果, 織 維の毛せん状集合体の他に良く成長した針状結晶が多く なり，さらに針状結晶も不規則集合体を呈してくる（図 2). 平均成長速度約 $0.02 \mathrm{~mm} / \mathrm{h}$, 最大約 $0.1 \mathrm{~mm} / \mathrm{h}$ で めった。

固-液界面反応と溶解一析出反応を区別することは容易 でないが，少なくとも両反応の大きな相違は，前者の中 に核形成過程がないことであり，そのために種子勃果は ない䉪である. そこで別に乾燥系で合成した六チタン酸 カリウムの粉末を用いた場合とルチルと炭酸カリウムの 各粉末の混合物を用いた場合を $1200^{\circ} \mathrm{C}, 5$ 時閒の反応で 比較したのが図 3 である.こ秃から六チタン酸カリウム を出発原料に用いた場合怡殆んぞ成長せず種子効果のな いことがわかり，固一液界面反応を推定することができ

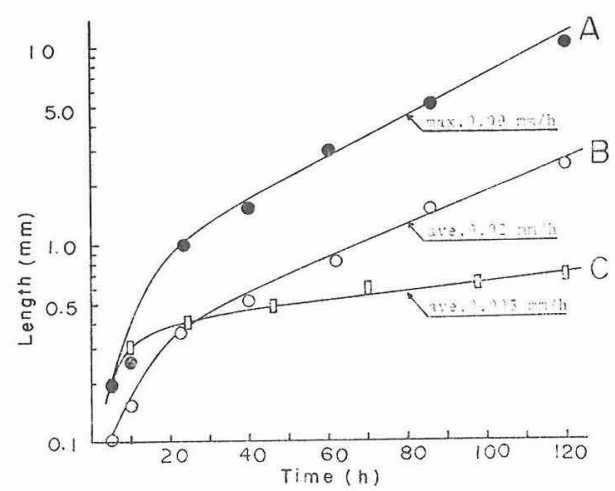

Fig. 1. Length of potassium titanate fibers grown at $1180^{\circ} \mathrm{C}$ for various reaction time in a $\mathrm{K}_{2} \mathrm{MoO}_{4}$ flux melt;

curve-A : maximum length of potassium hexatitanate fibers,

curve- $B$ : average length of potassium hexatitanate fibers,

curve-C : average length of the mixed fibers of potassium hexatitanate and tetratitanate.

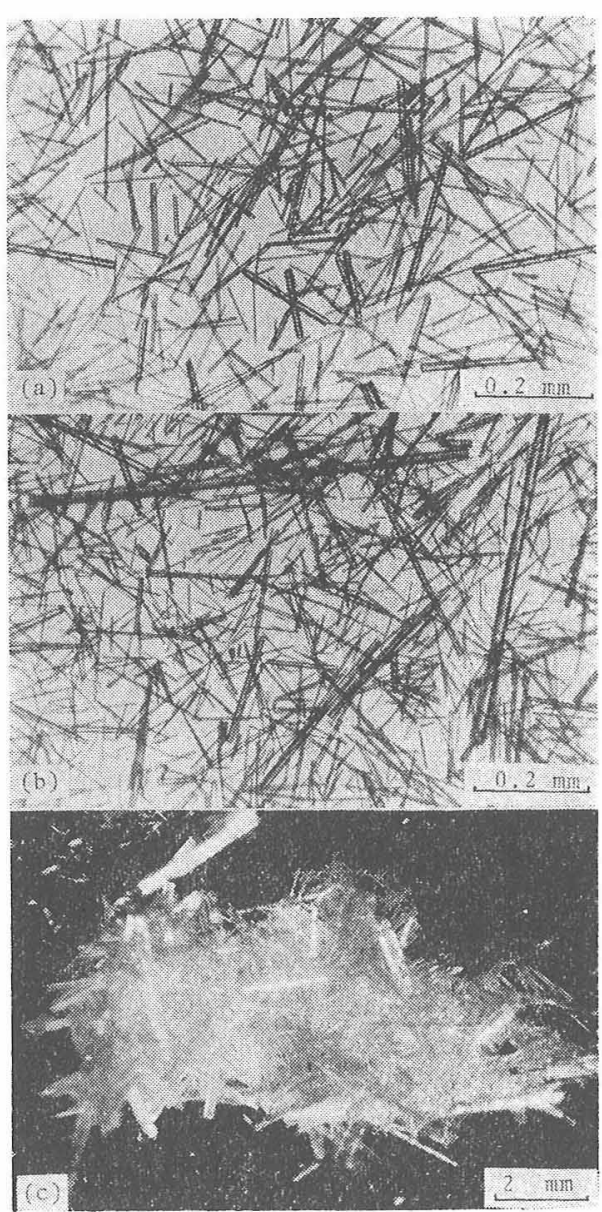

Fig. 2. Potassium hexatitanate fibers grown at $1180^{\circ} \mathrm{C}$ for various reaction time in a $\mathrm{K}_{2} \mathrm{MoO}_{4}$ flux melt (curve-B in Fig. 1);

(a) $5 \mathrm{~h}$, (b) $23 \mathrm{~h}$, (c) $120 \mathrm{~h}$. 


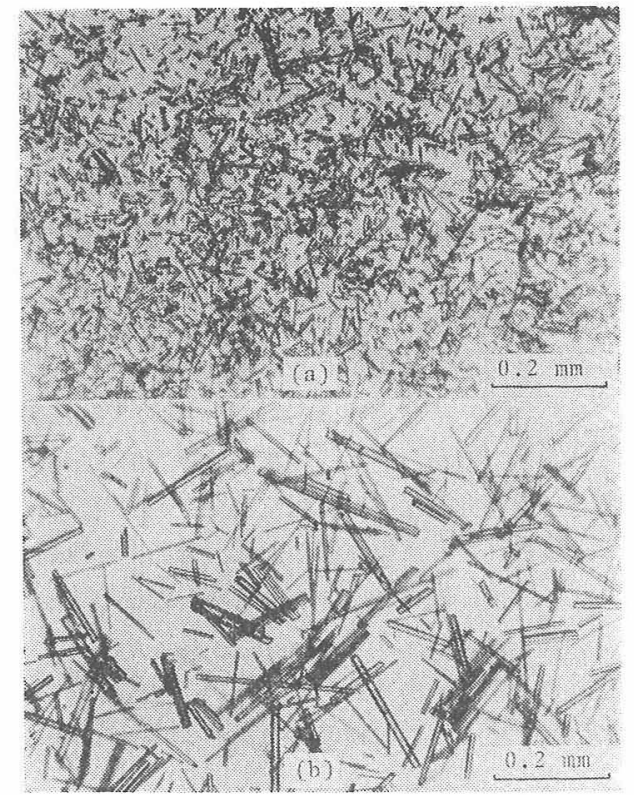

Fig. 3. No seed effect on the solid-liquid interface reaction is shown at the earlier stage in the flux reaction; (a) potassium hexatitanate fibers obtained at $1200^{\circ} \mathrm{C}$ for $5 \mathrm{~h}$ from the system $\mathrm{K}_{2} \mathrm{Ti}_{6} \mathrm{O}_{13}-\mathrm{K}_{2} \mathrm{MoO}_{4}$, (b) potassium hexatitanate fibers grown at $1200^{\circ} \mathrm{C}$ for $5 \mathrm{~h}$ from the system $\mathrm{TiO}_{2}-\mathrm{K}_{2} \mathrm{O}-\mathrm{K}_{2} \mathrm{MoO}_{4}$.

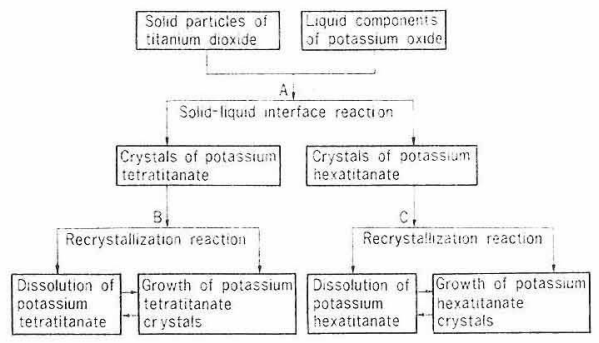

Fig. 4. The flux reaction scheme for potassium titanate formation from the system $\mathrm{K}_{2} \mathrm{O}$ $\mathrm{TiO}_{2}-\mathrm{K}_{2} \mathrm{MoO}_{4}$ (or $\mathrm{K}_{4} \mathrm{WO}_{4}$ ).

る.以上述ベたチタン酸カリウム緎維の合成反応の概略 图 4 亿示寸，この図中のA 反応汃固一液界面反応，B 及びC 反応が溶解一析出反応汇相当する。従って, 拡散 律速反応に基づく前者の反応速度は出発原料の二酸化于 タンの反忘活性，つまり比表面積に関係した微粒子性に 大きく依存し, 後者の反応浪過飽和度が成長速度に大き な影響を与えることが予想されるがこれれらについては 短瀻維及び長瀻維の合成の項で詳しく述べる。

図 1 中の $\mathrm{C}$ 曲線は $\mathrm{K}_{2} \mathrm{MoO}_{4}$ フラックス上 $x=1 / 4$ の 出発組成を用いて一定温度保持法 (蒸発法) で合成した 六チタン酸カリウム上四チタン酸カリウムの混合相瀻維

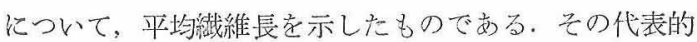
な繊維の集合状態を図 5 亿示す、これから混合相の初期

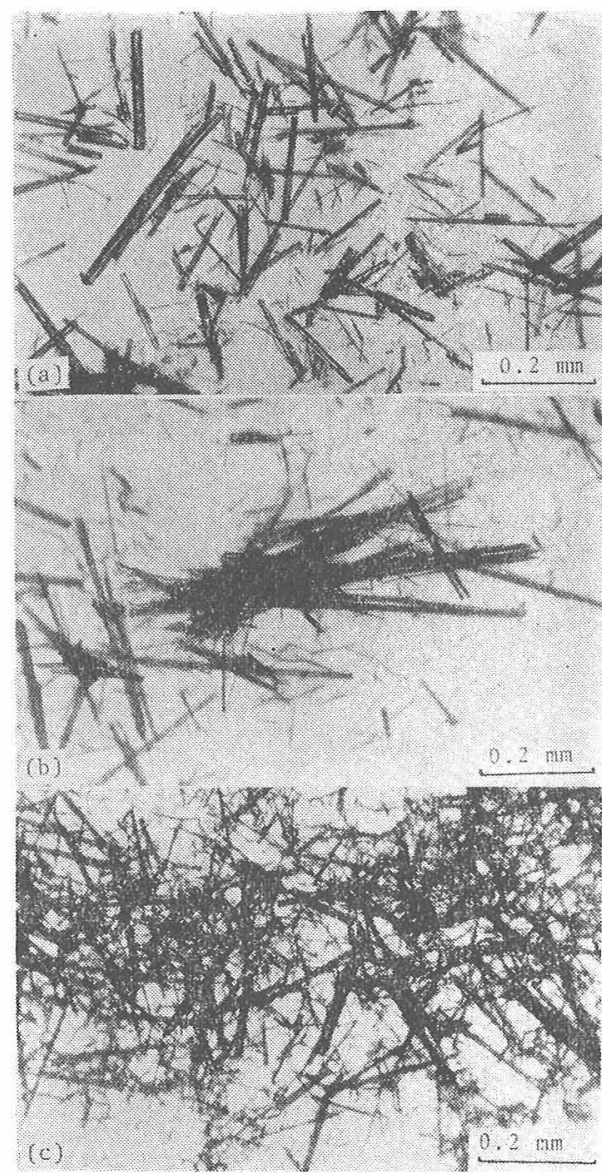

Fig. 5. The mixed fibers grown at $1180^{\circ} \mathrm{C}$ for various reaction time in a $\mathrm{K}_{2} \mathrm{MoO}$, flux melt (curve-C in Fig. 1);

(a) $5 \mathrm{~h}$, (b) $10 \mathrm{~h}$, (c) $120 \mathrm{~h}$.

の固-液界面反岕は六チタン酸カリウ二単独相の場合上 りも優勢であるが，溶解一析出反応では劣るこ上がわか る. 平均成長速度注約 $0.003 \mathrm{~mm} / \mathrm{h}$ であった。混合相が このような条件下で成長しない理由法，繊維性がよいた

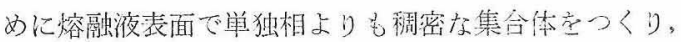
フラックス成分の蒸発を一層妨害方たたに過飽和度が 小さく, 㱠んど平衡に近い状態になりや子、たわ上思わ

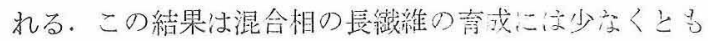
蒸発法以外の资成方法索用いる必要が高る上ニ暗示し ている.

\section{4 㵶維性と集合形}

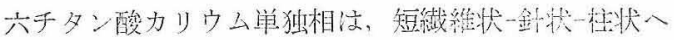

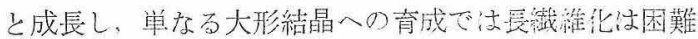
な挙動を示す。しかし，四チタン酸力リウム相坊微量で も共存すると，既に述へたように集合状態が暴深り瀻維 性が向上寸る。図 6 亿集合状態の比較定示す，混合相住 束状集合体, つ交り先端が細く引き裂かれて箔状を呈导 るのが大きな特徵である。この種の集合体の中で雨相を 


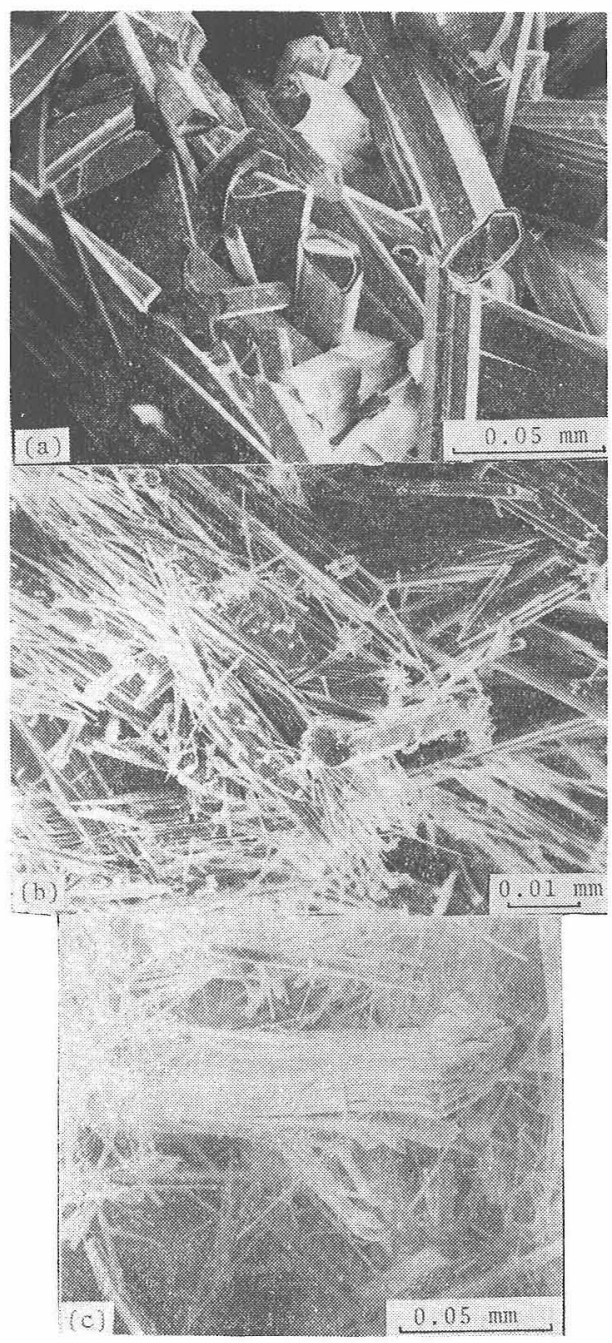

Fig. 6. The mode of aggregation of potassium titanate fibers; (a) potassium hexatitanate fibers grown at $1220^{\circ} \mathrm{C}$ for $48 \mathrm{~h}$ in a $\mathrm{K}_{2} \mathrm{MoO}_{4}$ flux melt, (b) and (c) the mixed fibers of potassium hexatitanate and tetratitanate grown at $1200^{\circ} \mathrm{C}$ for $26 \mathrm{~h}$ in a $\mathrm{K}_{2} \mathrm{MoO}_{4}$ flux melt (SEM-image).

区別することは困難である。

混合祖で繊維性が向上寸る原因は，既に述べたように 四チタン酸カリウム単独唱の䋊維を本フラックス中で合 成できないので，その纎維状態が不明のため明らかでな いが，集合状態の特徵を鉱物集合体の観点から推定する と次の二つの現象が考えられる，その一つとして結晶の 成長過程に衫ける引き裂かれ現象の関与が推定される。 この種の現象は天然鉱物にはよく知られており, ソーダ 沸石や束沸石なざにみられるように結晶の両端から裂開 し, ひ斥状から束状に, そして最後には球顆状になる17〕。 この引き裂かれ現象の原因は明確ではないが，含有不純 物の不規則分布や熱膨脹係数の異方性, 成長が非常に速
いことなどが原因であると言われている ${ }^{17)}$ 、本繊維の場 合は少なくとも 2 相が接触集合して同時に成長すること により起こっているので，異相相互が固体介在物的作用 をなしこの種の原因をなしているかも知れない，

一方，図6(c) のよらに裂開の方位に規則性があり， 結晶学的䢃開の可能性もある。これを六チタン酸カリウ ムと仮定すれば（100）面に平行に䢃開しており，その 構造5からも説明はできる。一般に結晶䢃開は外部応力 により起こる現象であるが，ここでは成長過程で自発的 に起こっている，その理由は不明であるが，異相集合体 のまま成長するため，その成長状態の相違から相境界面 の剝離及び暴相介在などが㖣開を誘発するものと考えら れる。一度䢃開すれば熔融液が対流で䢃開中を流動する ことによっても促進され，とくに密度の大きい䀄融淮の ためこの效果法ありそうである.

いずれにしても，引き裂かれ現象か，自発擘開かを一 義的に区別することは困難であるが，ここでは異相集合 体であることが緎維性を向上させている。

\section{5 短瀻維の合成}

六チタン酸カリウム単独相でも四チタン酸カリウムと の混合相でも $1 \mathrm{~mm}$ 以下の短繊維を主体に合成する場合 仿，前述のように生成初期段階の固-液界面反応が最も 重要である.これは塩基性分の $\mathrm{TiO}_{2}$ 固体中への拡散律 速反応であるから， $\mathrm{TiO}_{2}$ 固体粉末の比表面䅡に関係し た微粒子性の高いものほど反応活性とたり反応速度を高 めるであろう，従って $\mathrm{TiO}_{2}$ の出発原料の相違からその 情報を得ることができる。

まず，アナターゼ (II)，アナターゼ (I)，ルチルの 3 種類について 5 及び 10 時間の反応に対する平均繊維 長の結果を図 7 に示す. 反応 10 時間まではアナターゼ (II)>アナターゼ(I)>ルチルの順となった. 各出発試 料の反応活性程度を正確に知ることは困難であるが，簡 単に固-液界面反忘活性は試料の比表面積に関係した微 粒子性に依存するとして，アナターゼ（Ｉ）とルチルの

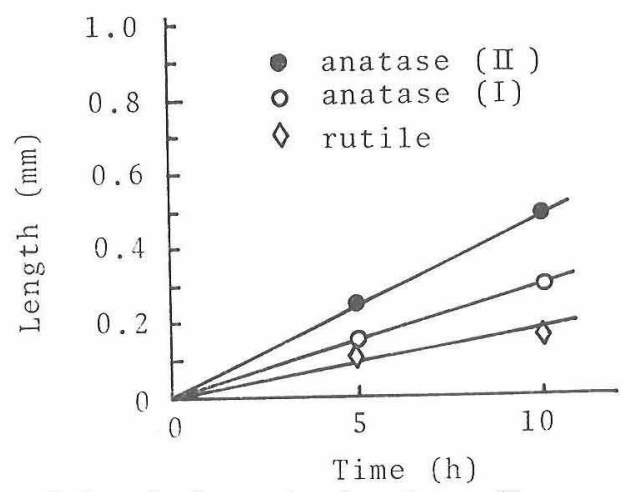

Fig. 7. Length of potassium hexatitanate fibers grown at $1200^{\circ} \mathrm{C}$ for 5 and $10 \mathrm{~h}$ with a sequence of particle size of anatase(II) anatase( (I), and rutile. 
䊀子径を SEM 像で比較した結果, 前者は平均 $0.15 \mu \mathrm{m}$, 後者は平均 $0.6 \mu \mathrm{m}$ であった.勿論,アナターゼ (II) は ゲル状生成物のためいずれよりも小さい，従って，繊維 長加らみた反応速度は明らかに $\mathrm{TiO}_{2}$ 固体粒子径に依存 している. 図 8 に実際の繊維状態の比較を示寸が，アナ ターゼ（II）の纎維が極めて細くて長いのは原料 $\mathrm{TiO}_{2}$

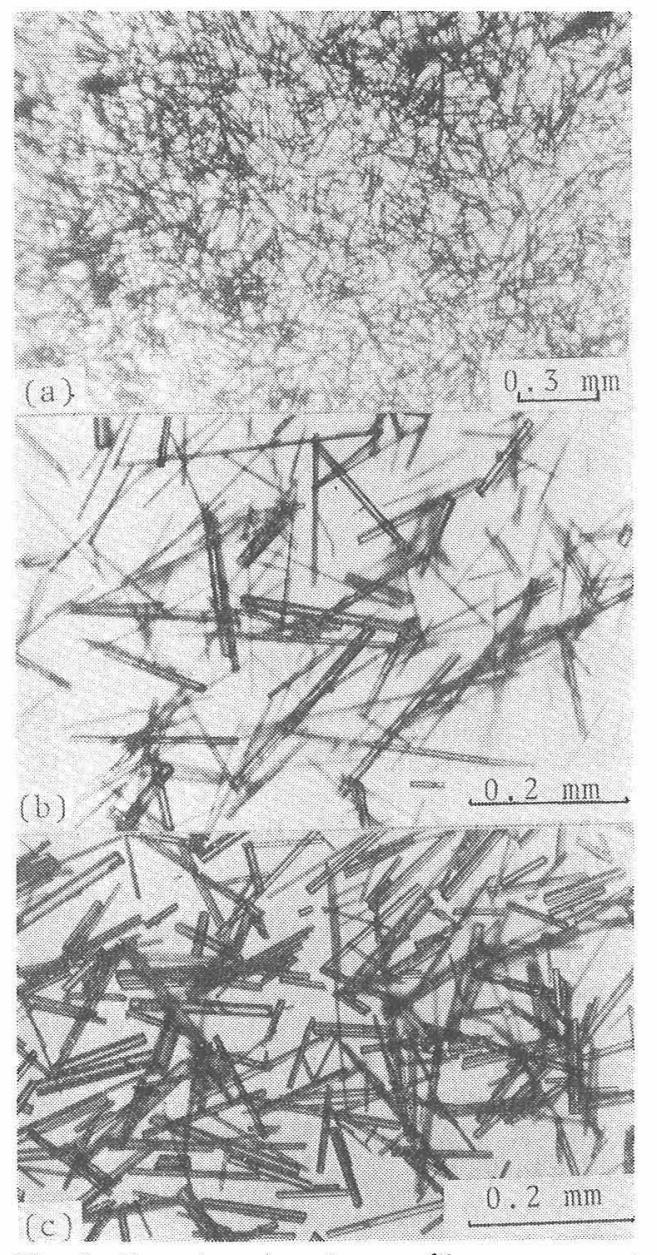

Fig. 8. Potassium hexatitanate fibers grown at $1200{ }^{\circ} \mathrm{C}$ for $5 \mathrm{~h}$ with various $\mathrm{TiO}_{2}$ particle sizes; a) anatase(II), b) anatase (I), c) rutile
の粒径と密接に関係しており，固-液界面反応の特徴と して良く説明ができる.

\section{6 長織維の育成}

$1 \mathrm{~mm}$ 以上の長繊維を育成するためには初期段階の固 一液界面反応に続く溶解-析出反応効果を高めることが重 要である.そのためには過飽和状態の制御が必要であり， 最も簡単な技術的操作としては, 徐冷法, 蒸発法, 温度差 法がある．蒸発法はすでに述べたように，フラックスの 蒸気压が低、のみならず，熔融液と合成物の大きい比重 差により生成䋊維が熔融液表面を抢㧍らために蒸発を防 止するので効果が少ない（表 1 2 は一定温度下での反 応のため蒸発法の結果としてみてもよい), 温度差法は 本実験の上うに原料の充填度が大きいと效果は少ない が，ある程度小さいと有効であろう。そこで最も有效と 思われる徐泠法による育成結果を表 3 亿示寸，長繊維化 への最適組成条件は繊維性の項で述べたように六チタン 酸カリウム相に僅が四チタン酸カリウム相が共存するこ とである. 同一組成条件では一定温度保持法（蒸発法） よりも同じ反応時閒に対して数倍繊維を長くすることが できる、しかし，六チタン酸カリウム単独相は徐冷法で も成長が遅い，その理由は四チタン酸カリウムより化学 的に安定 解一析出反応效果が減少寸るもの上推定される. この場 合には高温下での蒸発法が温度差法の方が有効である。 結局, 混合相繊維の徐冷法による溶解一析出反応効果が 大きいのは，四千タン酸カリウムの溶解度が大きいため と思われる (図 9).

\section{7 形態むよび格子定数}

$\mathrm{K}_{2} \mathrm{MoO}_{4}$ 及び $\mathrm{K}_{2} \mathrm{WO}_{4}$ フラックスから得られた六于 タン酸カリウムの針状結晶は単結晶の $\mathrm{X}$ 線回折によれ ば $b$ 軸方向に伸長し，良く発達した代表的六角柱面は $\{100\} ，\{401\} ，\{403\}$ などである.顕微鏡で観察すると， $b$ 軸方向への稜成長がその垂直方向よりも速いため, し ばしば空洞が認められ，断熱性を高为る一つの原因とな っている.

粉末法X線回折加ら単斜晶系 $C_{2} / m$ 空間群を用いて計

Table 3. Growth conditions and results by the slow cooling method using the fluxes of $\mathrm{K}_{2} \mathrm{MoO}_{4}$ and $\mathrm{K}_{2} \mathrm{WO}_{4}$.

\begin{tabular}{|c|c|c|c|c|c|c|}
\hline No. & $\begin{array}{l}\text { Starting composition } \\
(\mathrm{mol} \%)\end{array}$ & $\underset{(\operatorname{mol} \%)}{\text { Flux }}$ & $\begin{array}{c}\text { Temperature } \\
\text { High } \rightarrow \text { Low }\left({ }^{\circ} \mathrm{C}\right)\end{array}$ & Products* & $\begin{array}{l}\text { External } \\
\text { form }\end{array}$ & $\begin{array}{l}\text { Average length }{ }^{* * *} \\
(\mathrm{~mm})\end{array}$ \\
\hline 1 & $\left(\mathrm{~K}_{2} \mathrm{O}\right)_{1 / 6} \cdot \mathrm{TiO}_{2} 30$ & $\mathrm{~K}_{2} \mathrm{O} \cdot \mathrm{MoO}_{3} 70$ & $1200 \rightarrow 960$ & $\mathrm{H}$ & fiber & $0.25(0.5)$ \\
\hline 2 & $\left(\mathrm{~K}_{2} \mathrm{O}\right)_{1 / 3} \cdot \mathrm{TiO}_{2} 30$ & $\mathrm{~K}_{2} \mathrm{O} \cdot \mathrm{MoO}_{3} 70$ & $1200 \rightarrow 900$ & $\mathrm{H}+\mathrm{T}$ & $\begin{array}{l}\text { bunchy } \\
\text { fiber }\end{array}$ & $5.0 \quad(10.0)$ \\
\hline 3 & $\left(\mathrm{~K}_{2} \mathrm{O}\right)_{1,4} \cdot \mathrm{TiO}_{2} 30$ & $\mathrm{~K}_{2} \mathrm{O} \cdot \mathrm{MoO}_{3} 70$ & $1200 \rightarrow 950$ & $\mathrm{H}+\mathrm{T}$ & $"$ & $5.0 \quad(10.0)$ \\
\hline 4 & $\left(\mathrm{~K}_{2} \mathrm{O}\right)_{1 / 3} \cdot \mathrm{TiO}_{2} 30$ & $\mathrm{~K}_{2} \mathrm{O} \cdot \mathrm{MoO}_{3} 70$ & $1200 \rightarrow 960$ & $\mathrm{H}+\mathrm{T}$ & $"$ & $2.0 \quad(5.0)$ \\
\hline 5 & $\mathrm{TiO}_{2} 30$ & $\mathrm{~K}_{2} \mathrm{O} \cdot \mathrm{WO}_{3} 70$ & $1200 \rightarrow 970$ & $\mathrm{H}+\mathrm{R}$ & fiber & $0.15(0.4)$ \\
\hline 6 & $\left(\mathrm{~K}_{2} \mathrm{O}\right)_{1.6} \cdot \mathrm{TiO}_{2} 20$ & $\mathrm{~K}_{2} \mathrm{O} \cdot \mathrm{WO}_{3} \quad 80$ & $1200 \rightarrow 1000$ & $\mathrm{H}+\mathrm{T}$ & $\begin{array}{l}\text { bunchy } \\
\text { fiber }\end{array}$ & $5.0 \quad(10.0)$ \\
\hline 7 & $\left(\mathrm{~K}_{2} \mathrm{O}\right)_{1,5} \cdot \mathrm{TiO}_{2} 30$ & $\mathrm{~K}_{2} \mathrm{O} \cdot \mathrm{WO}_{3} \quad 70$ & $1200 \rightarrow 960$ & $\mathrm{H}+\mathrm{T}$ & " & $3.0(5.0)$ \\
\hline 8 & $\left(\mathrm{~K}_{2} \mathrm{O}\right)_{1 / 4} \cdot \mathrm{TiO}_{2} 30$ & $\mathrm{~K}_{2} \mathrm{O} \cdot \mathrm{WO}_{3} 70$ & $1200 \rightarrow 980$ & $\mathrm{H}+\mathrm{T}$ & $"$ & $5.0 \quad(10.0)$ \\
\hline
\end{tabular}

* $\mathrm{H}$ : potassium hexatitanate, $\mathrm{T}$ : potassium tetratitanate, $\mathrm{R}$ : rutile

* Diameter of the bunchy fibers is very variable within less than $1 / 10$ for the length. 

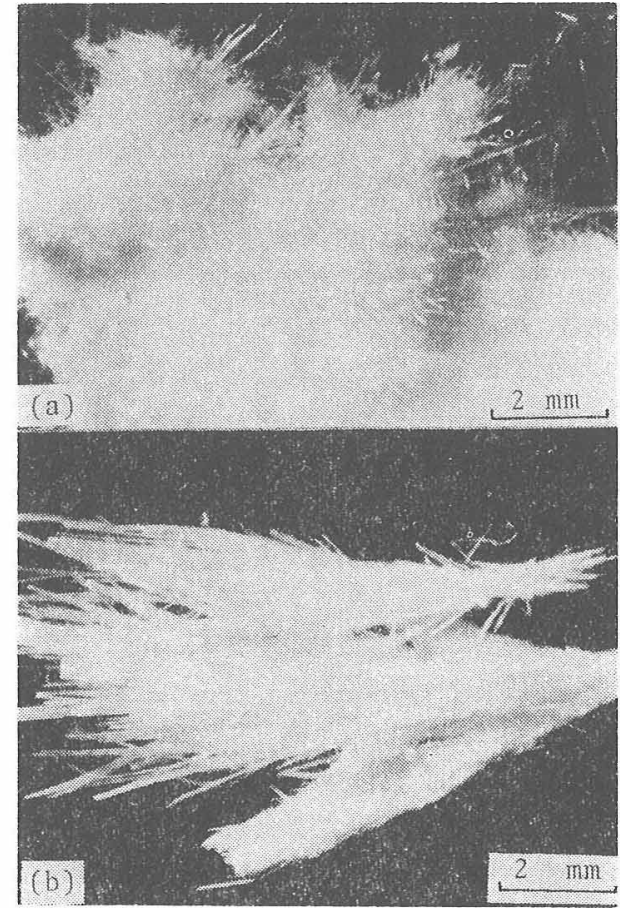

Fig. 9. The mixed fibers of potassium hexatitanate and tetratitanate grown by the slow-cooling method; (a) in a $\mathrm{K}_{2} \mathrm{MoO}_{4}$ flux melt, (b) in a $\mathrm{K}_{2} \mathrm{WO}_{4}$ flux melt.

算した六チタン酸カリウムの格子定数, 単位容積, 計算

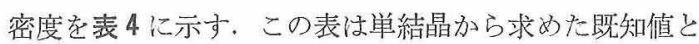
比皎れしているが良い一致を示している。

\section{4. 総括}

フラックス法によるチタン酸カリウム䋊維の合成には $\mathrm{K}_{2} \mathrm{MoO}_{4}$ と $\mathrm{K}_{2} \mathrm{WO}_{4}$ がフラックスとして非常に適してい る. 塩基性成分として $\mathrm{K}_{2} \mathrm{O}$, 酸性成分として $\mathrm{MoO}_{3}, \mathrm{WO}_{3}$ を添加することで熔融液の塩基性度を制御し，合成相を 選択することができる。

出発繊維組成を $\left(\mathrm{K}_{2} \mathrm{O}\right)_{x} \cdot \mathrm{TiO}_{2}$ 式で表わす上き, $\mathrm{K}_{2}$ $\mathrm{MoO}_{4}$ の場合は $x=1 / 6$ 以下, $\mathrm{K}_{2} W_{4}$ では $x=1 / 7$ 以下

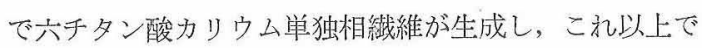
は四チタン酸カリウムとの混合相纎維が生成する.

本熔融液中の合成反応山, 初期段階で固一液界面反応 が優先し，続いて溶解一析出反応が優整となる，従って
Table 4. Lattice parameters of potassium haxatitanates.

\begin{tabular}{|c|c|c|c|c|c|c|c|}
\hline Composition & Flux & $a(\AA)$ & $b(\AA)$ & $c(\dot{\mathrm{A}})$ & $\beta$ & $V\left(\dot{A}^{3}\right)$ & $\rho\left(\mathrm{g} / \mathrm{cm}^{3}\right)$ \\
\hline $\mathrm{K}_{2} \mathrm{Ti}_{6} \mathrm{O}_{13}$ & $\mathrm{~K}_{2} \mathrm{MoO}_{4}$ & $\begin{array}{r}15.623 \\
\pm 0.006\end{array}$ & $\begin{array}{r}3.800 \\
\pm 0.001\end{array}$ & $\begin{array}{r}9.159 \\
\pm 0.004\end{array}$ & $\begin{array}{r}99.14 \\
\pm 0.01\end{array}$ & 1536.7 & 3.548 \\
\hline $\mathrm{K}_{2} \mathrm{Ti}_{6} \mathrm{O}_{13}$ & $\mathrm{~K}_{2} \mathrm{WO}_{4}$ & $\begin{array}{l}15.634 \\
\pm 0.005\end{array}$ & $\begin{array}{r}3.799 \\
\pm 0.001\end{array}$ & $\begin{array}{r}9.148 \\
\pm 0.004\end{array}$ & $\begin{array}{r}99.14 \\
\pm 0.01\end{array}$ & 536.4 & 3.551 \\
\hline $\mathrm{K}_{2} \mathrm{Ti}_{6} \mathrm{O}_{13} *$ & $\begin{array}{l}\text { melt } \\
\text { growth }\end{array}$ & $\begin{array}{r}15.582 \\
\pm 0.006\end{array}$ & $\begin{array}{r}3.82 \\
\pm 0.01\end{array}$ & $\begin{array}{r}9.112 \\
\pm 0.001\end{array}$ & 99.76 & - & 3.581 \\
\hline $\mathrm{K}_{2} \mathrm{Ti}_{6} \mathrm{O}_{13}{ }^{* * *}$ & $\begin{array}{l}\text { melt } \\
\text { growth }\end{array}$ & 15.60 & 3.80 & 9.13 & 99.6 & - & 3.58 \\
\hline
\end{tabular}

* H. Cid-Dresdner and M.J. Buerger (1962) ${ }^{52}$

** K.L. Berry et al. (1960) $)^{4)}$

短繊維の合成には前者の, 長繊維の合成に法後者の反応 が重要である。

とくに溶解析出反応に上る六チタン酸カリウム単独 㥵繊維の育成にはできるだけ高温での蒸発法か温度差法 が適し，四チタン酸カリウムとの混合相繊維の育成には 徐冷法が最適で方る。

（本研究の一部法昭和 50 年第 20 回人工碳物討論会で発表し ました)。

\section{文献}

1) E.K. Belyaev, et al., Inorg. Mater., 10, 395 (1974).

2) A.J. Easteal and D.J. Udy, IHigh Temp. Sci., 4, 487 (1972).

3) U.S.P. 3328117 (1967).

4) K.L. Berry, et al., J. Inorg. Nucl. Chem., 14, 231 (1960).

5) H. Cid-Dresdner and M.J. Buerger, Z. Kristallogr., 117, 411 (1962).

6) U.S.P. 2841470 (1958).

7) 斎藤㢣, 田草川信雄, 工化, 67, 297 (1964).

8) A.J. Easteal and D.J. Udy, J. Mater. Sci., 8, 1171, (1973).

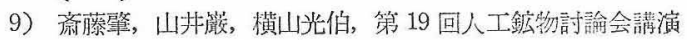
要旨集, p. 71, (1974).

10) U.S.P. 2833620 (1958).

11）武藤文夫, 国富稔, 工化，65, 1775 (1962).

12）滝貞男, 田中桂子, 工化, 66, 417 (1963).

13）清水紀夫, 橋本甲四郎, 柳田博明, 点協, 83，305（19 75).

14）清水紀夫，橋本甲四郎，柳田博明，短協，84，36 (1976).

15) A.L. Plumley and W.C. Orr, J. Am. Chem. Soc., 83, 1289 (1961).

16) A.M. Shams ElDin and A.A. ElHossary., J. Electroanal. Chem., 9, 349 (1965).

17) D.P. Grigorev, "Ontogeny of Minerals", Israel Programme for Scientific Translations, Jerusalem (19 $65)$. 